\title{
The Impact of Supply Chain Risks and Supply Chain Risk Management Strategies on Enterprise Performance in Ghana
}

\author{
Sherif Abdul Ganiyu* (1), Dong Yu, Chaoyi Xu, Alimasi Mongo Providence $(\mathbb{1})$ \\ School of Economics and Management, Anhui University of Science and Technology, Huainan, China \\ Email: ^abdulganiyusherif1@gmail.com,ydong@aust.edu.cn, 3910379@qq.com, providenceal@yahoo.com
}

How to cite this paper: Ganiyu, S. A., Yu, D., Xu, C. Y., \& Providence, A. M. (2020). The Impact of Supply Chain Risks and Supply Chain Risk Management Strategies on Enterprise Performance in Ghana. Open Journal of Business and Management, 8 , 1491-1507.

https://doi.org/10.4236/ojbm.2020.84095

Received: June 4, 2020

Accepted: June 30, 2020

Published: July 3, 2020

Copyright $\odot 2020$ by author(s) and Scientific Research Publishing Inc. This work is licensed under the Creative Commons Attribution International License (CC BY 4.0).

http://creativecommons.org/licenses/by/4.0/

\section{(c) (i) Open Access}

\begin{abstract}
Enterprises are constantly experiencing higher levels of supply chain disruptions in their operations due to the expansion of industries' business networks. It becomes very necessary for enterprises to continually assess risks in their business operations. To mitigate the adverse consequences of such potential supply chain risks on the performance of enterprises, it becomes imperative for Ghanaian enterprises to implement adequate supply chain risk management strategies. The purpose of this paper is to outline potential risks in the supply chain network of Ghanaian enterprises and investigate the impact of these potential risks and supply chain risk management (SCRM) strategies on enterprise performance. Data for the study was collected from 210 enterprises in Ghana and analyzed by modeling the constructs of supply chain risks, supply chain risk management (SCRM) strategies and enterprise performance and also measuring the complex relationships among the constructs using a structural approach. The structural model result shows that, enterprises with distinct organizational structures dedicated to supply chain risk management with the purpose of mitigating supply chain risks tend to perform better than their competitors. The results also indicated a negative association between supply chain risks and the performance of Ghanaian enterprises. This research provides direction for managers to adopt and develop adequate enterprise supply chain risk register and supply chain risk management (SCRM) strategies to mitigate the consequences of supply chain risks in their planned business operations.
\end{abstract}

\section{Keywords}

Supply Chain Risk, Organizational Performance, Supply Chain Risk Management, Structural Equation Modeling, Enterprise, Ghana 


\section{Introduction}

A supply chain is made up of a firm or group of firms whose business activities and processes are associated with the movement of raw materials, products, services, information and capital from their source to the final consumer (Butilca et al., 2011). Although supply chains differ significantly in size and nature, their ground laying principles are applicable in all business enterprises regardless of the size (Basu, 2011). The Council of Supply Chain Management Professionals (2009) asserts that Supply Chain Management (SCM) refers to the planning, management and coordination of all business-related activities among supply chain members to improve operating efficiency. Supply chain management (SCM) can then be seen as the active management and effective coordination of supply chain activities to leverage strategic positioning by increasing customer value and achieving a competitive advantage. Supply chain management exists to overcome the gap among different participants or stakeholders within a supply chain until the ultimate consumer (Waters, 2011). Chopra \& Sodhi (2004) contended that, most enterprises implement strategic plans to protect their planned business operations against frequent low-impact risks in their supply chain; many however, ignore the consequences of high-impact and low-probability risks. Effective supply chain management requires proper coordination and collaboration of all supply chain members to leverage strategic positioning and improve operational efficiency.

It is clear in the $21^{\text {st }}$ Century that, manufacturing firms cannot compete successfully in the extended world market without an effective and operational supply chain network. Globalization has become more intense in the past years and supply chains have become more diffused and extended in nature exposing major links within the supply chain network to risk (Kirilmaz \& Erol, 2017). As more companies and industries expand their business process to meet the increasing demands of customers and competition in the market, managers are frequently pressured to improve the efficiency and effectiveness of their supply chains, making transportation of materials within and outside the organization cheaper and faster, reducing the inventory cost and use of just-in-time (JIT) deliveries or lean inventories. Hauser (2003) suggested that enterprises should place a high priority on developing adequate supply chain management strategies to improve financial performance and to achieve competitive advantage considering today's increasingly complex environment of business.

Supply Chain disruptions are becoming more prevalent in Ghanaian enterprises due to the complex and nested nature of supply chain networks. Supply Chain in Ghana cut across all sectors of the economy and as enterprises are beginning to realize the significance of adequate supply chain risk management (SCRM) process in their operations, about $83 \%$ of enterprises still experience some forms of disruption in their operations. The frequent disruptions in the supply chain of businesses emanate from the complex nature of supply chain networks (Wagner \& Neshat, 2012). The unstable economy and lack of ideas in 
mitigating supply chain disruptions are the strategic difficulties for most enterprise managers in Ghana (Sodhi et al., 2012). Most Ghanaian enterprises find it difficult to cope with external business partners due to supply chain uncertainties and the global complexity of supply chain networks (Simangunsong et al., 2012). Over the past years, Ghanaian enterprises have extended their business operations to countries with more efficient and effective supply chain networks like the US, China and the UK (Dey, 2016).

Wright \& Datskovska (2012) revealed the impact that modification in the business scope and process have on operations and supply chains management. They argue that, while globalization might have enhanced operational efficiency, local concentrated risks become globally nested in nature consisting of several dimensions of risks in the supply chain network.

Unexpected outcomes and the economic difficulties related to the dynamic nature of business, volatile demand, market uncertainty and varying levels of trust among members of supply chain network indicate that enterprises face constant supply chain risks.

As many enterprises are considering and targeting performance enhancement possibilities in their supply chain network (Fabbe-Costes \& Jahre, 2008; Sari, 2008), there is a need to identify risks and devise strategic measures to mitigate or eliminate such unexpected consequences in the supply chain. Giannakis \& Papadopoulos (2016) suggested the need for enterprises to have advanced and sustainable approaches in mitigating supply chain risks. Jahre (2017) recommended a framework that enterprises can use to mitigate supply chain risks in their planned business operations by developing adequate and effective humanitarian supply chain strategies.

This paper seeks to identify risks in the supply chain network of enterprises in Ghana. More specifically, this paper attempts to 1) identify and validate key Supply chain risks in Ghanaian enterprises, 2) outline effective supply chain risk management (SCRM) strategies to mitigate the identified risks, and 3) investigate the impact of supply chain risks and supply chain risk management (SCRM) strategies on performance of Ghanaian enterprises.

This research paper is structured as follows. The dynamics of supply chain risks, supply chain risk management strategies and organizational performance are presented in Section 2 while the methodology and its application to the context under study are described in Section 3. The research results from the data analysis and the justification of the research implication are discussed in Section 4. Some conclusions and recommendations end the paper.

\section{Literature Review on Supply Chain Risks}

The likelihood of an undesired outcome to occur is referred to as "risk" (Rowe, 1977). The most common terms extensively used in literature to describe the nature of risk are "possibility" and "undesired". Rescher (1983) defined risk as an unpredictable event with possible undesired outcomes. The Supply Chain 
Risk Leadership Council (2011), defined "supply chain risk" as the probability and consequences of events at any stage in the end-to-end supply chain network starting from sources of raw materials to end use of customers, and then defined "Supply-Chain Risk Management (SCRM)" as the effective coordination and management of all business activities to regulate an enterprise's end-to-end supply chain network placing higher priorities on supply chain risks. The March, 2011 Tohoku earthquake and subsequent tsunami in Japan indicates how a single disruption can interrupt important global supply chain drivers such as supply, manufacturing, distribution and communication (Lee \& Pierson, 2011). The global economic implication of this disaster was estimated to cost US $\$ 139$ billion (Arto et al., 2015). In critical cases, a single disruption at a particular location can severely distort the plan operations of enterprises and sometimes, extreme consequences of the disruption may cause the business to fold out of operations. A common scenario that caused huge losses to business is the case of Ericsson. This disaster led to an estimated loss of US $\$ 400$ million to Ericsson (Norrman \& Jansson, 2004). The most recent disruption in the global supply chain network is the outbreak of the corona virus (COVID-19) in China. China's manufacturing sector is expected to have a nearly $2 \%$ reduction in production due to the virus outbreak resulting in a significant impact on all sectors of production such as the automobile industry, electronics industry, pharmaceutical industry, etc. The European Union automobile industry is predicted to see a drastic reduction in automobile and parts export from china due to the outbreak estimating to cost about US $\$ 2.5$ billion. Global pharmaceutical industries are also expected to experience a huge loss in the production of antibiotics and painkillers because China produces nearly $40 \%$ of the major ingredients of these drugs. According to the US Institute for Supply Management (ISM, 2020) about $95 \%$ of companies are predicted to experience various forms of supply chain disruptions due to the COVID-19 outbreak. Toyota's production was disrupted in 2011 after an earthquake, a tsunami and a nuclear crisis that occurred in Japan, resulting in an estimated loss of US $\$ 72$ million daily in profits (Autonews 2011). Consequently, this disruption has led to a $77 \%$ fall in Toyota's net income for the first quarter of 2011 (Canis, 2011).

Risk in the supply chain comprises of all events that might disrupt the movement of goods and services in an enterprise (Waters, 2011). Sodhi et al. (2012) after a thorough supply chain literature review indicate that most researchers in the field consider supply chain risk management (SCRM) a subset of supply chain management (SCM), which involves developing adequate strategies to mitigate disruption and supply-demand stochastic with additional focus on risks and strategies dealing with uncertain disruptions and supply-demand volatility.

Risks sometimes provide positive results but in general, it is associated with undesired outcomes. Risk can be described as a potential variation in expected outcomes; this variation can either be a desired outcome or undesired outcome (Williams et al., 1998). This idea of risks is shown by many researchers in the supply chain risk management field who concur to the knowledge that supply 
chain risks are generally associated with the probability of loss, damage and undesired outcomes (Wagner \& Bode, 2008).

For the purpose of this research, we concur with the many researchers in the field of supply chain risk management such as Wagner \& Bode (2008) and establish that supply chain risks are associated with only undesired outcomes.

Generally, a possible collection of pairs of likelihood $(L)$ and Outcomes $(O)$ can be termed as Risk. Mathematically; Risks in an enterprise can be described as a function of likelihood $(L)$ and Outcomes $(O)$, that is;

$$
\text { Risk }=\left\{\left(L_{1} O_{1}\right),\left(L_{2} O_{2}\right),\left(L_{3} O_{3}\right), \cdots,\left(L_{n} O_{n}\right)\right\}
$$

$L_{i}=$ probability of occurrence of risk.

$O_{i}=$ potential losses of risk.

Ayyub (2003) established that the arrangement sequence of likelihood and outcome pairs is known as a "risk profile". The international organization for standardization (ISO, 2002) explained two of the important constituents of risk as; losses experienced along with its related amount and the probability of occurrence. These and several other definitions of risks provided by researchers in the field of supply chain risk management are consistent with literature that implies two constituent of risk:

1) Potential losses (what will be the impact of the consequences of the losses and what losses will result if the risk occurs) (Harland et al., 2003; Manuj \& Mentzer, 2008; Mitchell, 1995); and

2) Probability of the occurrence (the likelihood of the event occurring).

There are many ways of identifying and classifying risks within the business environment. Juttner et al. (2003) documented that risk can be classified based on sources of risks: 1) environmental risk sources, 2) network risk sources and 3) organizational risk resources. Chopra \& Sodhi (2004) opined that risks can be classified on the basis of supply-related risks, demand-related risks and contextual risks. According to Tang \& Tomlin (2008), supply chain risk can be categorized into supply risk, process risks and demand risks. Manuj \& Mentzer (2008) categorized supply chain risks based on 1) supply, 2) operational, 3) demand, 4) security, 5) macro, 6) policy, 7) competitive, and 8) resource risks. Oke \& Gopalakrishnan (2009) opined that supply chain risks can be classified by considering low-impact high-rate of occurrence and high-impact low-rate of occurrence risks in three significant areas: 1) supply, 2) demand, and 3) miscellaneous risks in the retail sector. According to Rao \& Goldsby (2009), supply chain risks can also be categorized as: 1) framework risk, 2) problem-specific risk, and 3) decision making risk. Risks may also be identified by examining extremely important uncertainties in scenario planning (Garvin \& Levesque, 2006).

What follows is a classification of supply chain risks, concentrating on the identification of risk categories in the entire supply chain network of enterprises in Ghana. We also sought empirical evidence on the impact of supply chain risks and supply chain risk management strategies on organizational performance in Ghanaian enterprises through a review of the literature. 
Vikulov \& Butrin (2014) suggested a classification of supply chain risks by considering risks in specific points in the supply chain network. These risks are identified at major links within the entire supply chain network of enterprises and then categorized. These researchers categorized supply chain risk based on 1) suppliers, 2) transport, 3) warehousing and 4) production.

For the purpose of this study, we adapt the supply chain risks classification proposed by Vikulov \& Butrin (2014) as shown in Table 1.

\subsection{Supply Chain Risk Management Strategies}

Supply Chain Risk Management (SCRM) attempts to mitigate the disruptions in supply chains via a well-structured and organized approach by identifying potential supply chain risks along several links or nodes within the supply chain network of an enterprise. The strategies are implemented to mitigate the adverse consequences of supply chain vulnerability. Wagner \& Bode (2008) opined that coping with supply chain risks requires adequate and effective supply chain risk management strategies. Table 2 shows the indicators and measurement items of supply chain risk management strategies.

\subsection{Indicators of Organizational Performance}

Organizational performance can be measured by considering how enterprises leverage their strategic positioning in achieving both its market-oriented and financial goals. Organizational performance constitutes the actual output of an organization as compared to its expected output. According to Richard et al. (2009) performance of organizations can be measured based on three unique aspects of firm outcomes 1) based on financial performance (profits, return on assets, return on investment, etc.), 2) based on product market performance

Table 1. Supply chain risks.

\begin{tabular}{|c|c|c|}
\hline Risk Category & Risk Composition & Indicator Variable \\
\hline \multirow{4}{*}{$\begin{array}{l}\text { Risks Associated } \\
\text { with Suppliers }\end{array}$} & Delivery Schedule & $\mathrm{X} 1$ \\
\hline & Poor quality & $\mathrm{X} 2$ \\
\hline & Prices & $\mathrm{X} 3$ \\
\hline & Non-delivery/Non-delivery & $\mathrm{X} 4$ \\
\hline \multirow{2}{*}{$\begin{array}{l}\text { Risks Associated } \\
\text { with Transport }\end{array}$} & Damage of goods in transit & $\mathrm{X} 5$ \\
\hline & Loss of goods in transit & X6 \\
\hline \multirow{3}{*}{$\begin{array}{c}\text { Risks Associated } \\
\text { with Warehousing }\end{array}$} & Damage of goods during storage & $\mathrm{X} 7$ \\
\hline & Changes in taxes and other cost of warehousing & $\mathrm{X} 8$ \\
\hline & Quality problems & X9 \\
\hline \multirow{3}{*}{$\begin{array}{l}\text { Risks Associated } \\
\text { with Production }\end{array}$} & Overproduction & $\mathrm{X} 10$ \\
\hline & Disruptions due to equipment failure & $\mathrm{X} 11$ \\
\hline & Disruptions due to procurement failure & $\mathrm{X} 12$ \\
\hline
\end{tabular}

Source: Adaptation from Vikulov \& Butrin (2014: p. 45). 
Table 2. Indicators of supply chain risk management (SCRM) strategies.

\begin{tabular}{clc}
\hline Indicators & \multicolumn{1}{c}{ Measurement Items } & $\begin{array}{c}\text { Variable } \\
\text { Indicator }\end{array}$ \\
\hline Supplier Collaboration & $\begin{array}{l}\text { Collaboration with suppliers to develop transparent } \\
\text { supply chains and an open sharing of information }\end{array}$ & SCRM1 \\
Continuity or Contingency Plan & $\begin{array}{l}\text { Business continuity or contingency plans addressing } \\
\text { several supply chain risks }\end{array}$ & SCRM2 \\
$\begin{array}{c}\text { Product Innovation or } \\
\text { Differentiation }\end{array}$ & Product differentiation for reducing demand side risks & SCRM3 \\
$\begin{array}{c}\text { Dedicated SCRM Structure } \\
\text { Insurance }\end{array}$ & A distinct organization structure dedicated to SCRM & SCRM4 \\
\hline
\end{tabular}

Source: Adaptation from Khan \& Burnes (2017).

(sales, market share, etc.) and 3) based on shareholder return (total shareholder return, economic value added, etc.). Many researchers (such as Cao \& Zhang, 2011; Vickery, Calantone, \& Droge, 1999; Stock, Greis, \& Kasarda, 2000) indicated that organizational performance can be measured using both financial and market indicators including market share, return on investment (ROI), the growth of market share, growth of return on investments (ROI), the profit margin on sales, and overall competitive advantage. Based on the above literature, four measurement indicators were adapted to measure organizational performance in Ghanaian enterprises. Table 3 shows the indicators and measurement items of Organizational performance.

\section{Research Methodology}

The research commenced with the identification of potential risks in an enterprise's supply chain, indicators of supply chain risk management strategies and organizational performance based on literature review. The process resulted in establishment of 12 major risks that affect the supply chain of enterprises in Ghana. These risks were further grouped into 4 risk categories. The next step was developing a structural equation model to analyze the impact of these potential supply chain risks and supply chain risk management strategies on the performance of Ghanaian enterprises.

\subsection{Conceptual Framework}

Existing supply chain risk management literature indicates that supply chain disruptions can lead to loss of both short term sales and long term market share, implying that enterprises that are exposed to supply chain disruptions can anticipate having lower performance compared to firms who do not have a greater level of exposure to disruptions. The research work of Wagner \& Bode (2008); Wagner \& Neshat (2012) documented the negative impact of supply chain risks on the performance of enterprises. Following these researchers, we formulate our first hypothesis as: 
Table 3. Indicators of organizational performance.

\begin{tabular}{ccc}
\hline Dimension & Measurement Items & Variable Indicator \\
\hline Profit & Average profit over the last three years & OP1 \\
Cost & Average cost over the last three years & OP2 \\
Return on Investment (ROI) & Average ROI over the last three years & OP3 \\
Sales & Increase in Sales over the last three years & OP4 \\
\hline
\end{tabular}

Source: Adaptation from Cao \& Zhang (2011).

Hypothesis 1: Supply chain risks are negatively associated with the performance of enterprises.

Supply Chain Risk Management (SCRM) attempts to mitigate supply chain disruptions via a well-structured and organized approach by identifying and analyzing the risk of failure nodes within the entire supply chain network of an enterprise. Therefore, enterprises can start mitigating the consequences of risks in the supply chain by prioritizing and developing adequate supply chain risk management strategies. According to Wagner \& Bode (2008), effective communication of enterprise priorities and measures put in place to mitigate risks in the entire Supply chain network of enterprises is essential in achieving organizational performances considering the present unstable business market. Li Suhong et al. (2006) reported that enterprises that place a higher priority on the practices of higher levels of supply chain management (SCRM \& ERM) can expect to have an improvement in organizational performance and enhanced competitive advantage. Kamalahmadi \& Parast (2017) also documented that enterprise that invests in developing capabilities to mitigate supply chain risks tend to enjoy positive benefits including better performance. Thus we formulate our second hypothesis as:

Hypothesis 2: Supply chain risk management (SCRM) strategies impact positively on enterprise performance.

Therefore to analyze the relationship between supply chain risks, SCRM strategies and enterprise performance, we propose the conceptual framework presented in Figure 1.

\subsection{Why Structural Equation Modeling}

Structural Equation Modeling (SEM) is a series of statistical estimations that allows modeling of complex associations between one or more exogenous variables and one or more endogenous variables in a model. Our choice for structural equation modeling (SEM) was by the premise that, SEM is the most dominant research methodology widely used in supply chain research (Kumar \& Nambirajan, 2013). The SEM approach has spread widely as a result of the development of unique statistical packages such as LISREL and AMOS. Joreskog \& Sorbom (1999) and Arbuckle \& Worthke (1999) found that the accessibility of these statistical packages has encouraged a widespread application in various contexts. Statistical estimation involving the SEM approach permits the modeling 


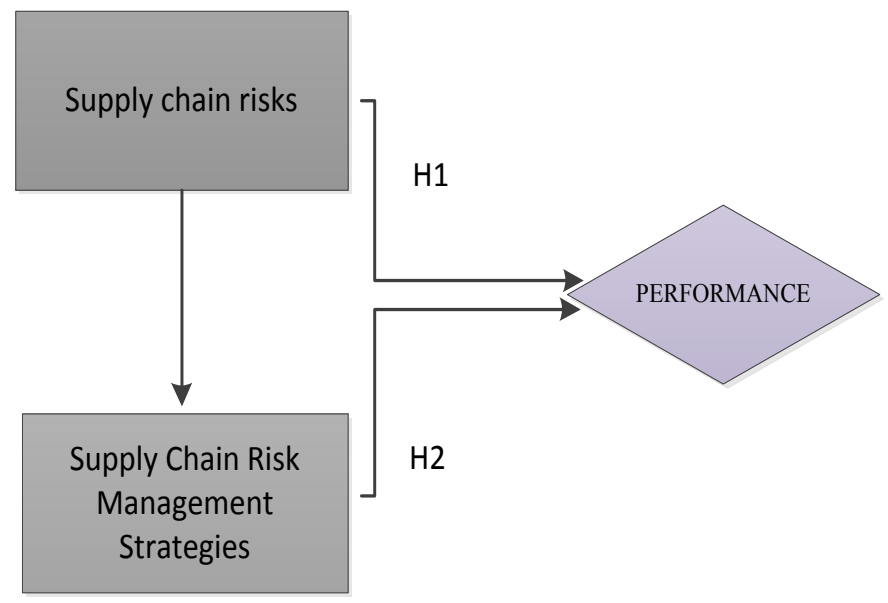

Figure 1. Conceptual model.

of an event by considering both the unobserved "latent" constructs and the observed "manifest" constructs that describe the process.

\subsection{Data Collection}

A survey-based questionnaire was used for the data collection. The questionnaire was close-ended in 3 sections. Section 1 requires respondents (enterprises) to assess the impact of risks on their supply chain. Section 2 requires respondents to assess the various SCRM strategies in their enterprise and Section 3 requires respondents to assess the performance of their enterprise over a period of time. 210 valid questionnaires were usable after distributing 250 questionnaires. The questionnaire used in this study is adapted from (Cao \& Zhang, 2011; Vikulov \& Butrin, 2014; Khan \& Burnes, 2007). Data was analyzed using IBM SPSS 25.0 and IBM AMOSS 24.0 software. The estimated effective recovery rate of questionnaires was $84 \%$.

\subsection{Sample Size}

A theoretical rule of thumb about the connection between sample size and complex models which is supported by empirical researches was documented by Jackson (2003) as the N:q rule. This rule is suitable when the statistical estimation method employed is the maximum likelihood (ML), which is by far the most prevalent method used in SEM.

Jackson (2003) suggested that, researchers should consider the minimum sample size as a ratio of cases $(\mathrm{N})$ to the required estimated number parameters in the model (q). According to Kline (2011) a minimum sample size of 200 cases is required in studies where SEM is used; that said, a sample size of 200 cases may not be enough to achieve model fit when analyzing a complex model. Muthén \& Satorra (1995) suggested that a minimum sample size of 150 cases is required for a non-complex confirmatory factor analysis (CFA) model with normally distributed continuous factors without missing data cases to achieve a power of 0.81 to statistically reject the hypothesis that the factor correlation is 
zero. For the purpose of our study, we use a sample size of 210 cases which is consistent with Jackson's (2003) opinion.

\subsection{Evaluation of Structural Model}

Evaluation and specification of the structural model was based on empirical results from literature review, informed judgment and combination of theories used in previous supply chain management researches. Variables that were used for the evaluation of the structural model are illustrated in Table 4.

Table 4. Variables in the structural model.

\begin{tabular}{|c|c|c|}
\hline Latent variable & Manifest variable & How to measure \\
\hline \multirow{14}{*}{ Supply Chain Risks } & X1-Delivery schedule & \\
\hline & $\mathrm{X} 2$-Prices & \\
\hline & X3-Non-delivery/Short delivery & To assess the impact of these \\
\hline & X4-Poor quality & Potential supply chain risks on \\
\hline & X5-Damage of goods in transit & Performance of Ghanaian \\
\hline & X6-Loss of goods in transit & $\begin{array}{l}\text { enterprises-responses were } \\
\text { made }\end{array}$ \\
\hline & X7-Damage of goods during storage & on a 6-point scale \\
\hline & $\begin{array}{l}\text { X8-Changes in taxes and other costs of } \\
\text { warehousing }\end{array}$ & $\begin{array}{c}\text { (1-Very low impact, to 6-Very } \\
\text { high impact) }\end{array}$ \\
\hline & X9-Quality problems & \\
\hline & X10-Over production & \\
\hline & X11-Disruptions due to equipment failures & \\
\hline & X12-Disruptions due to procurement failures & \\
\hline & $\begin{array}{l}\text { SCRM1-Our firm collaborates with suppliers } \\
\text { to develop transparent supply chains and } \\
\text { open sharing of information }\end{array}$ & \\
\hline & $\begin{array}{l}\text { SCRM2-Our firm has a business continuity } \\
\text { or contingency plan addressing several } \\
\text { supply chain risks }\end{array}$ & $\begin{array}{l}\text { To assess how Ghanaian } \\
\text { enterprises implement supply } \\
\text { chain }\end{array}$ \\
\hline $\begin{array}{l}\text { Supply Chain Risk } \\
\text { Management } \\
\text { strategies }\end{array}$ & $\begin{array}{l}\text { SCRM3-Our firm use product differentiation } \\
\text { for reducing demand side risks }\end{array}$ & $\begin{array}{l}\text { management } \\
\text { strategies-responses were made } \\
\text { on a 6-point scale }\end{array}$ \\
\hline \multirow[t]{3}{*}{$(\mathrm{SCRM})$} & $\begin{array}{l}\text { SCRM4-Our firm has a distinct organization } \\
\text { structure dedicated to supply chain risk } \\
\text { management }\end{array}$ & $\begin{array}{l}\text { (1-Extremely disagree, to } \\
\text { 6-Extremely agree) }\end{array}$ \\
\hline & $\begin{array}{l}\text { SCRM5-Our firm has insurance against } \\
\text { supply chain risks }\end{array}$ & \\
\hline & OP1-Average profits over the last three years & To assess the performance of \\
\hline $\begin{array}{l}\text { Organizational } \\
\text { Performance }\end{array}$ & OP2-Average costs over the last three years & Ghanaian enterprises-responses \\
\hline \multirow[t]{2}{*}{$(\mathrm{OP})$} & OP3-Average ROI over the last three years & were made on a 6-point scale \\
\hline & OP4-Increase in sale over the last three years & $\begin{array}{l}\text { (1-Extremely worse, to } \\
\text { 6-Extremely better) }\end{array}$ \\
\hline
\end{tabular}




\subsection{Results and Analysis}

The structural model analysis consists of statistical estimation using maximum likelihood (ML) approach since the data for the analysis was multivariate normally distributed. The evaluation of model fit is to confirm the theoretical model by means of fitting parameters. To evaluate the model fit indices, AMOS 24.0 software was used to calculate the model parameters and the required indices obtained. Review of previous researches (by Hu \& Bentler, 1995; Burnham \& Anderson, 2002; Hoyle \& Panter, 1995; Steiger, 2007; Wen et al., 2004) established that the general criteria for judging the fitting indices are as follows: 1) When $\chi^{2} / \mathrm{df}<3$, it indicates a good model. 2) When CFI $>0.95$, it means the model is a good fit, and when CFI $>0.90$, it indicates an acceptable model fit. 3) TLI $>0.90$ indicates an acceptable fit. 4) SRMR and RMSEA $<0.05$, it indicates a satisfactory model fit and when SRMR and RMSEA $<0.08$, it indicates an acceptable model-data fit. 5) Both GFI and AGFI are mandated to be greater than 0.85 .

After the analysis, it was found that a satisfactory model fit was achieved and the goodness-of-fit indices of the structural model satisfied all the required measurement criteria as shown in Table 5.

To examine the construct validity of the structural model, Bagozzi and Yi's (1998) composite reliability index and Fornell and Larcker's (1981) average variance extracted variance were used. The three reliability measure criteria to consider for convergent validity are: 1 ) standardize factor loadings are required to be statistical significance at 0.3 (Angsuchoti et al., 2008); 2) A minimum value of 0.6 is required to achieve composite reliability (CR) of the constructs, and 3) A minimum value of 0.5 is required for average variance extracted (AVE) (Diamantopoulos \& Siguaw, 2000). Convergent validity of constructs used to develop the structural model was achieved as shown in Table 6.

Critical Ratio (CR) greater than $1.96(\mathrm{CR}>1.96)$ indicates statistical significance for the estimated path parameter at $\alpha=0.05$ level or better.

\section{Discussion and Research Implications}

The result from the data analysis indicates the acceptance of all our proposed hypotheses. It was established that the variable supply chain risk (SCR) has a significant negative relationship with organizational performance. As supply chain risks are becoming more prevalent in Ghana, enterprises planned operations are disrupted which affects the overall performance of enterprises. This result is consistent with previous research work by Wagner \& Bode (2008), Wagner \& Neshat (2012) who reported a negative association between supply chain risks and organizational performance. Consequently hypothesis $\mathrm{H} 1$ is accepted.

Table 5. Fitting indices of structural model.

\begin{tabular}{cccccccccc}
\hline Fit Index & CMIN & DF & CMIN/DF & CFI & GFI & AGFI & RMSEA & TLI & SRMR \\
\hline Fitting Indices & 1313.673 & 191 & 1.642 & 0.933 & 0.921 & 0.851 & 0.055 & 0.926 & 0.0578 \\
\hline
\end{tabular}


Table 6. Results of structural model.

\begin{tabular}{|c|c|c|c|c|c|c|c|}
\hline $\begin{array}{c}\text { Latent } \\
\text { Variable }\end{array}$ & Item & $\begin{array}{l}\text { Standardized } \\
\text { Factor } \\
\text { Loading }\end{array}$ & $\begin{array}{c}\text { Standard } \\
\text { Error (SE) }\end{array}$ & $\begin{array}{c}\text { Critical } \\
\text { Ratio }\end{array}$ & $\begin{array}{c}\text { Average } \\
\text { Variance } \\
\text { Extracted (AVE) }\end{array}$ & $\begin{array}{c}\text { Composite } \\
\text { Reliability } \\
\text { (CR) }\end{array}$ & $\begin{array}{l}\text { Cronbach's } \\
\text { Alpha } \\
\text { Coefficient }\end{array}$ \\
\hline & OP1 & 0.849 & 0.059 & 16.163 & & & \\
\hline \multirow[t]{5}{*}{ OP } & OP2 & 0.871 & 0.054 & 16.931 & 0.733 & 0.912 & 0.916 \\
\hline & OP3 & 0.835 & 0.060 & 15.691 & & & \\
\hline & OP4 & 0.870 & - & - & & & \\
\hline & SCRM1 & 0.766 & - & - & & & \\
\hline & SCRM2 & 0.714 & 0.084 & 11.418 & & & \\
\hline \multirow[t]{8}{*}{ SCRM } & SCRM3 & 0.642 & 0.084 & 9.938 & 0.512 & 0.850 & 0.848 \\
\hline & SCRM4 & 0.816 & 0.084 & 13.775 & & & \\
\hline & SCRM5 & 0.700 & - & - & & & \\
\hline & $\mathrm{X} 1$ & 0.890 & - & - & & & \\
\hline & $\mathrm{X} 2$ & 0.544 & 0.137 & 7.592 & & & \\
\hline & $\mathrm{X} 3$ & 0.700 & 0.146 & 6.639 & & & \\
\hline & $\mathrm{X} 4$ & 0.891 & - & - & & & \\
\hline & $\mathrm{X} 5$ & 0.583 & 0.141 & 8.201 & & & \\
\hline \multirow[t]{7}{*}{ SCR } & $\mathrm{X} 6$ & 0.585 & 0.146 & 8.224 & 0.533 & 0.924 & 0.832 \\
\hline & $\mathrm{X} 7$ & 0.881 & - & - & & & \\
\hline & $\mathrm{X} 8$ & 0.640 & 0.155 & 9.113 & & & \\
\hline & X9 & 0.798 & - & - & & & \\
\hline & $\mathrm{X} 10$ & 0.608 & 0.139 & 8.591 & & & \\
\hline & $\mathrm{X} 11$ & 0.539 & 0.139 & 7.514 & & & \\
\hline & $\mathrm{X} 12$ & 0.782 & - & - & & & \\
\hline
\end{tabular}

For H2, the results supported that supply chain risk management (SCRM) strategies impact positively on organizational performance. This is probably because organizations that place a higher priority on developing and implementing adequate supply chain risk management strategies are able to mitigate the adverse consequences of risks in their supply chain network. This result is consistent with the research work of Li Suhong et al. (2006) who found that, placing a higher priority on developing and implementing supply chain management (SCM) practices can lead to enhanced operational efficiency and improve competitive advantage. Table 7 shows the results for the path coefficient and hypothesis testing.

\section{Conclusion}

Existing research on supply chain indicates the relevance of developing and implementing adequate supply chain risk management strategies for enhancing 
Table 7. Path coefficient and hypothesis testing.

\begin{tabular}{ccccc}
\hline Hypothesis & Relationship & Standard factor loadings & $P$-Value & Supported \\
\hline H1 & SCR $\rightarrow$ OP & -0.122 & 0.021 & Yes \\
H2 & SCRM $\rightarrow$ OP & 0.839 & $* * *$ & Yes \\
\hline
\end{tabular}

${ }^{* * *} P<0.001$.

organizational performance. This paper seeks to add to the already extended literature on supply chain risk management by providing new data and empirical knowledge about the impact of supply chain risks and supply chain risk management strategies on organizational performance in Ghanaian enterprises. Results suggest that enterprises in Ghana must develop distinct organizational structures dedicated to supply chain risk management to mitigate the consequences of supply chain disruption and enhance performance.

Finally, managers of enterprises should use the guidelines provided in this research in identifying and designing company risk register as well as supply chain risk management strategies to cope with recurrent supply chain risks.

Regardless of its limitations, this research paper offers valuable managerial knowledge on the measures required for achieving a risk-free supply chain network and paves the way for future research in the field such as extending the number of variables used in the analysis.

\section{Recommendation for Company}

1) Enterprises can use the constructs or variables used in the structural model formulated in this paper as a measure for developing a proper enterprise risk register. These variables are empirically proved to be closely related to supply chain risk management, which indicates that they are reliable measures for developing adequate organizational risk register. Organizations that developed an adequate risk register would be able to identify the immediate supply chain threats around their business operations and promptly devise strategies to mitigate such risks before they cause catastrophic losses over time. Organizations that developed their risk register would be able to identify the immediate supply chain risks around their business operations and as such will be able to mitigate such risk before they cause catastrophic losses.

2) Enterprises should occasionally monitor and review their risk register and supply chain risk strategies to timely identify and mitigate new supply chain risks in the course of business operation. As organizations expand their business operations, their supply chains are more exposed to new supply chain risks and as such new strategies need to be implemented quickly to mitigate the effect on organization planned operations.

\section{Conflicts of Interest}

The authors declare no conflicts of interest regarding the publication of this paper. 


\section{References}

Angsuchoti, S., Wijitwanna, S., \& Pinyopanuwat, R. (2008). Statistics for Social Science and Behavioural Science: How to Use LISREL. Bangkok: Mission Media. (In Thai)

Arbuckle, J. L., \& Worthke, W. (1999). AMOS 4.0 Users Guide [Computer Software Manual]. Chicago, IL: Smallwaters.

Arto, I., Andreoni, V., \& Rueda Cantuche, J. M. (2015). Global Impacts of the Automotive Supply Chain Disruption Following the Japanese Earthquake of 2011. Economics Systems Research, 21, 311-335. https://doi.org/10.1080/09535314.2015.1034657

Autonews, F. (2011). Opel, Renault Production Hit by Shortage of Japanese Parts. http://www.autonews.com/article/20110318/COPY01/303189860/opel-renault-product ion-hit-by-shortage-of-japanese-parts

Ayyub, B. M. (2003). Risk Analysis in Engineering and Economics. Boca Raton, FL: Chapman \& Hall/CRC Press. https://doi.org/10.1201/9780203497692

Bagozzi, R. P., \& Yi, Y. (1998). On the Evaluation of Structure Equation Models. Journal of the Academy of Marketing Science, 16, 76-94.

Basu, R. (2011). Managing Project Supply Chains. Farnham: Gower Publishing.

Burnham, K. P., \& Anderson, D. R. (2002). Model Selection and Inference: A Practical Information-Theoretical Approach (2nd Edition). New York: Springer.

Butilca, D., Crisan, E., Salanta, I., \& Ilies, L. (2011). The Adoption/Adaptation of the "Supply Chain" Concept in Romania. Annals of the University of Oradea, Economic Science Series, 20, 650-660.

Canis, B. (2011). Motor Vehicle Supply Chain: Effects of the Japanese Earthquake and Tsunami, Congressional Research Service.

Cao, M., \& Zhang, Q. (2011). Supply Chain Collaboration: Impact on Collaborative Advantage and Firm Performance. Journal of Operations Management, 29, 163-180. https://doi.org/10.1016/j.jom.2010.12.008

Chopra, S., \& Sodhi, M. (2004). Managing Risk to Avoid Supply Chain Breakdown. MIT Sloan Management Review, 46, 53-61.

Council of Supply Chain Management Professionals (2009). Supply Chain Management/Logistics Management Definitions.

https://cscmp.org/CSCMP/Academia/SCM_Definitions_and_Glossary_of_Terms/CSC MP/Educate/SCM_Definitions_and_Glossary_of_Terms.aspx?hkey=60879588-f65f-4ab 5-8c4b-6878815ef921

Dey, C. K. (2016). Strategies to Reduce Supply Chain Disruptions in Ghana. PhD Thesis, Minneapolis, MN: Walden University.

Diamantopoulos, A., \& Siguaw, A. D. (2000). Introducing LISREL: A Guide for the Uninitiated. London: Sage. https://doi.org/10.4135/9781849209359

Fabbe-Costes, N., \& Jahre, M. (2008). Supply Chain Integration and Performance: A Review of the Evidence. International Journal of Logistics Management, 19, 130-154. https://doi.org/10.1108/09574090810895933

Fornell, C., \& Larcker, D. (1981). Structural Equation Models with Unobservable Variables and Measurement Error: Algebra and Statistics. Journal of Marketing Research, 18, 382-388. https://doi.org/10.1177/002224378101800313

Garvin, D. A., \& Levesque, L. C. (2006). Meeting the Challenges of Corporate Entrepreneurship. Harvard Business Review, 84, 102-112.

Giannakis, M., \& Papadopoulos, T. (2016). Supply Chain Sustainability: A Risk Manage- 
ment Approach. International Journal of Production Economics, 171, 455-470. https://doi.org/10.1016/j.ijpe.2015.06.032

Harland, C. M., Brenchley, R., \& Walker, H. (2003). Risk in Supply Networks. Journal of Purchasing \& Supply Management, 9, 51-62. https://doi.org/10.1016/S1478-4092(03)00004-9

Hauser, L. M. (2003). Risk-Adjusted Supply Chain Management. Supply Chain Management Review, 7, 64-71.

Hoyle, R. H., \& Panter, A. T. (1995). Writing about Structural Equation Models. In R. H. Hoyle (Ed.), Structural Equation Modeling: Concepts, Issues, and Applications (pp. 158-176). Thousand Oaks, CA: Sage.

Hu, L., \& Bentler, P. M. (1995). Evaluating Model Fit. In R. H. Hoyle (Ed.), Structural Equation Modeling: Concepts, Issues, and Applications (pp. 76-99). Thousand Oaks, CA: Sage.

Institute for Supply Management (2020). COVID-19 Survey: Impacts on Global Supply Chain. https://www.instituteforsupplymanagement.org/news/NewsRoomDetail.cfm?ItemNum ber $=31171 \& \mathrm{SSO}=1$

ISO (2002). ISO/IEC Guide 73-Risk Management-Vocabulary-Guidelines for Use in Standards. Geneva: International Organization for Standardization. https://www.iso.org/standard/34998.html

Jackson, D. L. (2003). Revisiting Sample Size and Number of Parameter Estimates: Some Support for the N:Q Hypothesis. Structural Equation Modeling, 10, 128-141. https://doi.org/10.1207/S15328007SEM1001_6

Jahre, M. (2017). Humanitarian Supply Chain Strategies-A Review of How Actors Mitigate Supply Chain Risks. Journal of Humanitarian Logistics and Supply Chain Management, 7, 82-101. https://doi.org/10.1108/JHLSCM-12-2016-0043

Joreskog, K. G., \& Sorbom, D. (1999). LISREL 8 User's Guide. Chicago, IL: Scientific Software International.

Juttner, U., Peck, H., \& Christopher, M. (2003). Supply Chain Risk Management: Outlining an Agenda for Future Research. International Journal of Logistics, 6, 197-210. https://doi.org/10.1080/13675560310001627016

Kamalahmadi, M., \& Parast, M. M. (2017). An Assessment of Supply Chain Disruption Mitigation Strategies. International Journal of Production Economics, 184, 210-230. https://doi.org/10.1016/j.ijpe.2016.12.011

Khan, O., \& Burnes, B., (2007). Risk and Supply Chain Management: Creating a Research Agenda. International Journal of Logistics Management, 18, 197-216. https://doi.org/10.1108/09574090710816931

Kırılmaz, O., \& Erol, S. (2017). A Proactive Approach to Supply Chain Risk Management: Shifting Orders among Suppliers to Mitigate the Supply Side Risks. Journal of Purchasing and Supply Management, 23, 54-65. https://doi.org/10.1016/j.pursup.2016.04.002

Kline, R. B. (2011). Convergence of Structural Equation Modeling and Multilevel Modeling.

Kumar, C., \& Nambirajan, T. (2013). An Integrated Model for Supply Chain Management Components, Supply Chain Performance and Organizational Performance: Purification and Validation of a Measurement Instrument. The Journal of Contemporary Management Research, 8, 37-56.

Lee, D., \& Pierson, D. (2011). Disaster in Japan Exposes Supply Chain Flaw. Los Angeles 
Times, April 6, 2011.

https://www.latimes.com/business/la-xpm-2011-apr-06-la-fi-quake-supply-chain-2011 0406-story.html

Li, S. H., Ragu-Nathan, B., Ragu-Nathan, T. S., \& Rao, S. S. (2006). The Impact of Supply Chain Management Practices on Competitive Advantage and Organizational Performance. Omega, 34, 107-124. https://doi.org/10.1016/j.omega.2004.08.002

Manuj, I., \& Mentzer, J. T. (2008). Global Supply Chain Risk Management Strategies. International Journal of Physical Distribution and Logistics Management, 38, 192-223. https://doi.org/10.1108/09600030810866986

Mitchell, V. W. (1995). Organizational Risk Perception and Reduction: A Literature Review. British Journal of Management, 6, 115-133.

https://doi.org/10.1111/j.1467-8551.1995.tb00089.x

Muthén, B., \& Satorra, A. (1995). Complex Sample Data in Structural Equation Modeling. In P. Marsden (Ed.), Sociological Methodology 1995 (pp. 216-231). Washington DC: American Sociological Association. https://doi.org/10.2307/271070

Norrman, A., \& Jansson, U. (2004). Ericsson's Proactive Supply Chain Risk Management Approach after a Serious Sub-Supplier Accident. International Journal of Physical Distribution \& Logistics Management, 34, 434-456. https://doi.org/10.1108/09600030410545463

Oke, A., \& Gopalakrishnan, M. (2009). Managing Disruptions in Supply Chains: A Case Study of a Retail Supply Chain. International Journal of Production Economics, 118, 168-174. https://doi.org/10.1016/j.ijpe.2008.08.045

Rao, S., \& Goldsby, T. J. (2009). Supply Chain Risks: A Review and Typology. International Journal of Logistic Management, 20, 97-123. https://doi.org/10.1108/09574090910954864

Rescher, N. (1983). Risk: A Philosophical Introduction to the Theory of Risk Evaluation and Management. Lanham, MD: University Press of America.

Richard, P. J., Devinney, T. M., Yip, G. S., \& Johnson, G. (2009). Measuring Organizational Performance: Towards Methodological Best Practice. Journal of Management, 35, 718-804. https://doi.org/10.1177/0149206308330560

Rowe, W. D. (1977). An Anatomy of Risk. New York: John Wiley \& Sons.

Sari, K. (2008). Inventory Inaccuracy and Performance of Collaborative Supply Chain Practices. Industrial Management and Data Systems, 108, 495-509. https://doi.org/10.1108/02635570810868353

Simangunsong, E., Hendry, L. C., \& Stevenson, M. (2012). Supply-Chain Uncertainty: A Review and Theoretical Foundation for Future Research. International Journal of Production Research, 50, 4493-4523. https://doi.org/10.1080/00207543.2011.613864

Sodhi, M., Son, G., \& Tang, S. (2012). Researchers' Perspective on Supply Chain Risk Management. Production and Operations Management, 21, 1-13.

https://doi.org/10.1111/j.1937-5956.2011.01251.x

Steiger, J. H. (2007). Understanding the Limitations of Global Fit Assessment in Structural Equation Modeling. Personality and Individual Differences, 42, 893-898. https://doi.org/10.1016/j.paid.2006.09.017

Stock, G. N., Greis, N. P., \& Kasarda, J. D. (2000). Enterprise Logistics and Supply Chain Structure: The Role of Fit. Journal of Operations Management, 18, 531-547. https://doi.org/10.1016/S0272-6963(00)00035-8

Supply Chain Risk Leadership Council (2011). Supply Chain Risk Management: A Compilation of Best Practices. 
http://www.scrlc.com/articles/Supply_Chain_Risk_Management_A_Compilation_of_B est_Practices_final[1].pdf

Tang, C. S., \& Tomlin, B. (2008). The Power of Flexibility for Mitigating Supply Chain Risks. International Journal of Production Economics, 116, 12-27. https://doi.org/10.1016/j.ijpe.2008.07.008

Vickery, S., Calantone, R., \& Droge, C. (1999). Supply Chain Flexibility: An Empirical Study. Journal of Supply Chain Management, 35, 16-24. https://doi.org/10.1111/j.1745-493X.1999.tb00058.x

Vikulov, V., \& Butrin, A. (2014). Risk Assessment and Management Logistics Chains. Log Forum, 10, 43-49. http://www.logforum.net

Wagner, S. M., \& Neshat, N. (2012). A Comparison of Supply Chain Vulnerability Indices for Different Categories of Firms. International Journal of Production Research, 50, 2877-2891. https://doi.org/10.1080/00207543.2011.561540

Wagner, S., \& Bode, C. (2008). An Empirical Examination of Supply Chain Performance along Several Dimensions of Risk. Journal of Business Logistics, 29, 307-325. https://doi.org/10.1002/j.2158-1592.2008.tb00081.x

Waters, D. (2011). Supply Chain Risk Management: Vulnerability and Resilience in Logistics (2nd ed.). London: Kogan Page.

Wen, Z. L., Hau, K. T., \& Marsh, H. W. (2004). Structural Equation Model Testing: Cutoff Criteria for Goodness of Fit and Chi Square. Acta Psychologica Sinica, 36, 186-194.

Williams Jr., C. A., Smith, M. L., \& Young, P. C. (1998). Risk Management and Insurance (8th Edition). Boston, MA: Irwin McGraw-Hill.

Wright, J., \& Datskovska, D. (2012). Addressing Supply Chain Risks. Financ. Exec, 28, 63. 